\title{
Coleus monostachyus (P. Beauv.) A. J. Paton (Lamiaceae): A new addition to the flora of India
}

\author{
K. Subrahmanya Prasad ${ }^{1 *}$, P. Biju², K. Agretious Thomas ${ }^{1}$ \& E. J. Josekutty ${ }^{2}$ \\ ${ }^{1}$ Department of Botany, Nehru Arts and Science College, Kanhangad, Kasaragod 671 314, Kerala, India \\ ${ }^{2}$ Department of Botany, Govt. College Kasaragod, Kasaragod 671 121, Kerala, India \\ ^Email: prasadks83@gmail.com
}

\section{OPEN ACCESS}

\section{ARTICLE HISTORY}

Received: 26 October 2021

Accepted: 19 January 2022

Available online

Version 1.0: 21 February 2022

\section{Check for updates}

\section{Additional information}

Peer review: Publisher thanks Sectional Editor and the other anonymous reviewers for their contribution to the peer review of this work.

Reprints \& permissions information is available at https://horizonepublishing.com/ journals/index.php/PST/open_access_policy

Publisher's Note: Horizon e-Publishing Group remains neutral with regard to jurisdictional claims in published maps and institutional affiliations.

Indexing: Plant Science Today, published by Horizon e-Publishing Group, is covered by Scopus, Web of Science, BIOSIS Previews, Clarivate Analytics, etc. See https:// horizonepublishing.com/journals/index.php/ PST/indexing_abstracting

Copyright: $\odot$ The Author(s). This is an openaccess article distributed under the terms of the Creative Commons Attribution License, which permits unrestricted use, distribution and reproduction in any medium, provided the original author and source are credited (https://creativecommons.org/licenses/ by/4.0/)

\section{CITE THIS ARTICLE}

Prasad K S, Biju P, Thomas K A, Josekutty E J. Coleus monostachyus (P. Beauv.) A. J. Paton (Lamiaceae): A new addition to the flora of India. Plant Science Today. 2022;9(sp1):9-11. https://doi.org/10.14719/pst.1561

\begin{abstract}
Coleus monostachyus (P. Beauv.) A. J. Paton is reported here as a new addition to the flora of India. It seems the seeds of this plant might have come along with the timbers imported from the SE Asian countries. A detailed morphological description based on the Indian plants and photographs are provided to facilitate easy and correct identification.
\end{abstract}

\section{Keywords \\ Kasaragod, Kerala, India, Coleus monostachyus, Lamiaceae, new record}

\section{Introduction}

Coleus Lour. with about 300 species is one of the largest genera in the family Lamiaceae (1). It is distributed mainly in tropical and southern parts of Africa, Madagascar, Asia and Australia (2). Different researchers used their own generic delimitation keys for the sub-tribe Plectranthinae. This resulted in placing species under major generic names like Plectranthus L'Her., Coleus Lour. and Solenostemon Thonn. (3). Later, morphological studies conducted by different workers synonymized all these names under Plectranthus $(2,4)$. Phylogenetic analysis suggested the need for generic delimitation in Plectranthinae and recognition of Coleus, Plectranthus and Equilabium as separate genera (5). As per this suggestion, in 2019, the generic status of Coleus has been reinstated with 294 species (1).

During the recent floristic explorations in the Kasaragod District of Kerala, the authors collected an interesting species of Coleus. A perusal of relevant literature (6-8) and consulting authentic herbarium specimens deposited at Kew Herbarium (K) [available at apps.kew.org/herbcat/ navigator.do], National Museum of Natural History, Paris (P) [available at https://science.mnhn.fr/institution/mnhn/search], Global Plants on JSTOR (available at https://plants.jstor.org), REFLORA - Plants of Brazil (available at reflora.jbrj.gov.br), the specimens were identified as Coleus monostachyus (P. Beauv.) A. J. Paton. This species is a native of tropical Africa, where it occurs as an annual weed in human habitats and rocky savannahs. Later, this plant became naturalized in Singapore (8), Malaysia (9) and Java Islands (10). Analysis of recent literature on Indian Plectranthinae (11-14) revealed that this species has not been reported from India. Hence, Coleus monostachyus is reported here as a new addition to the Indian flora with detailed description, photographic illustrations and ecological notes. 


\section{Taxonomic treatment}

\section{Coleus monostachyus}

(P. Beauv.) A. J. Paton, Phytokeys 129: 76. 2019; Ocimum monostachyum P. Beauv., Fl. Oware 2: 60. 1818; Plectranthus palisotii Benth., Labiat. Gen. Spec.: 39. 1832., nom. illeg; Solenostemon monostachyus (P. Beauv.) Briq. in Engler \& Prantl, Nat. Pflanzenfam. 4(3a): 359. 1897; Solenostemonocymoides var. monostachyus (P. Beauv.) Baker in $\mathrm{Fl}$. Trop. Afr. 5: 421. 1900; Plectranthus monostachyus (P. Beauv.) B. J. Pollard, Kew Bull. 56: 980. 2001. Fig. 1.

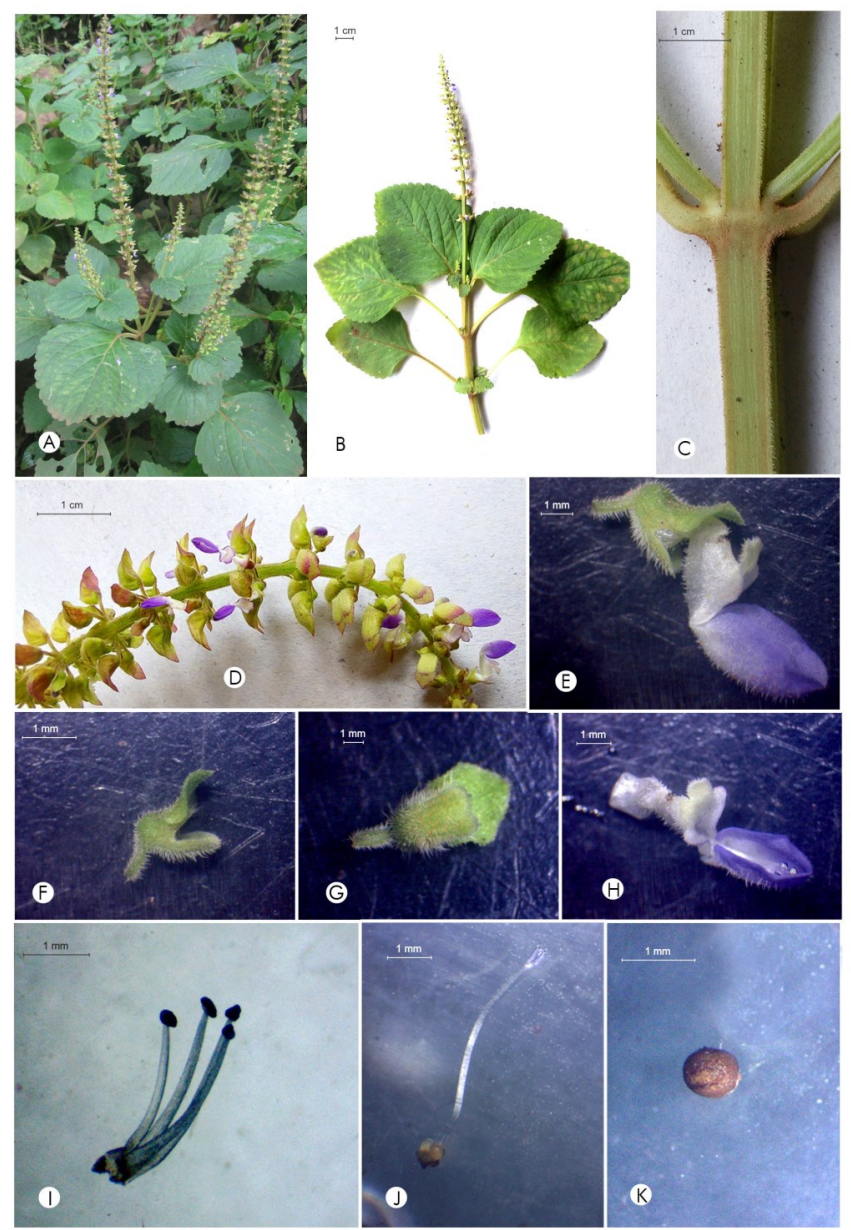

Fig. 1. Coleus monostachyus (P. Beauv.) A. J. Paton : A. Habit; B. Twig; C. A portion of stem; D. Inflorescence; E. Flower; F. Flowering calyx; G. Fruiting calyx; H. Corolla; I. Stamens; J. Gynoecium; K. Nutlet.

Erect or ascending or decumbent annual herb, up to $1 \mathrm{~m}$ high. Stems succulent, branched, quadrangular, aromatic, shortly pubescent along angles with simple hairs; internodes $5-7.5 \mathrm{~cm}$ long, 2-8 $\mathrm{mm}$ wide. Roots adventitious, 5-17 cm long. Leaves opposite, decussate, simple, slightly fleshy; stipules absent; petioles 2-9.5 cm long, pubescent along the angles; lamina broadly ovate, $2.4-13 \times$ 1.8-10.5 cm, glabrous above, puberulous and glanddotted below; base cuneate; apex obtuse to acute; margins crenate; lateral veins 5-6 pairs, projected and distinct below; venation eucamptodromous. Inflorescence of terminal, false spike, up to $40 \mathrm{~cm}$ long, consisting of sessile dichasia or verticillasters, simple or sometimes branched at inflorescence base; axis slender, pubescent; floral nodes distant, 5-13 mm apart; each verticillaster composed of 2 opposite cymes; cymes sessile, lax, 6-8-flowered; pedun- cles 2-5 cm long; bracts persistent, elliptic, 2.8-3 × 1.3-1.5 $\mathrm{mm}$, apex acuminate, margins ciliate; bracteole absent. Flowers bisexual, zygomorphic, 7.5-9 mm long, 4-4.5 mm in diameter; pedicels slender, $2.5-3 \mathrm{~mm}$ long, pubescent, inserted opposite to the posterior lip of calyx. Calyx greenish, campanulate, 2-lipped, somewhat scabrous with white patent hairs and yellowish glands on outer surface, $2-2.2 \times$ $0.8-1 \mathrm{~mm}$ at anthesis, enlarging to $4.8-5 \times 2.6-3 \mathrm{~mm}$ in fruit; upper tooth or posterior lip ovate; 2 lateral teeth shorter, linear and converge under the posterior lip; 2 lower teeth almost completely fused (anterior lip) leaving 2 minute projections, anterior lip curves upwards at maturity to close off calyx throat. Corolla bluish purple, with white base, 6-6.5 mm long, 2-lipped, pubescent outside, glabrous inside; tube conspicuously sigmoid; posterior lip erect, short, 4-lobed, white, lobes rounded at apex, median lobes (2-2.2 $\mathrm{mm}$ ) larger than lateral lobes (1.6-1.8 $\mathrm{mm})$; anterior lip boat shaped, 3.8-4 × 1.6-1.8 mm, concave, pubescent with sessile yellowish glands outside. Stamens 4, didynamous, attached at base, appendage absent, included within anterior lip of corolla; filaments of posterior pair 2-2.3 mm long, anterior pair 2.5-2.8 mm long; anthers yellowish, bilobed, dorsifixed, 0.1-0.15 mm long, dehiscing longitudinally. Disc white, $0.1-0.2 \mathrm{~mm}$ long, smaller and not exceeding ovary. Ovary superior, 4-celled, 0.3-0.4 mm high; style sigmoid, 4.8-5 mm long, glabrous; stigma bifid with equal lobes $(0.2-0.4 \mathrm{~mm})$. Nutlets brownish, orbicular, ca $0.8 \times 0.8 \mathrm{~mm}$, sculptured with very fine hairs, producing mucilage when moistened.

\section{Phenology}

\section{August-October.}

\section{Habitat and Ecology}

About 100 mature plants were found growing at moist shady place near road side on the sides of a lateritic hill along with herbaceous species such as Achyranthes aspera L., Hyptis suaveolens (L.) Poit., Justicia procumbens L., Ipomoea triloba L., Sida rhombifolia L. and Synedrella nodiflora (L.) Gaertn.

\section{Specimens Examined}

India, Kerala, Kasaragod district, Seethangoli, $12^{0} 36^{\prime} 02^{\prime \prime} \mathrm{N}$, 7500'22" E, 102 m a.s.l, 02.09.2021, K.S. Prasad 06418 (CALI).

\section{Notes}

Coleus monostachyus, commonly known as monkey's potato is a plant having both economic and ecological significance. In tropical Africa, it is used as a vegetable, employed in rituals related to pregnancy and leaf extract is recommended as a remedy for health conditions like fever, cough, headache, colic and convulsions (15-19). It is generally considered as a weed (8). Present collection location is situated near a saw mill which imports timbers from Malaysia. It is presumed that the seeds of this species might have reached the territory of India through imported wood. Introduction of this weedy species into a new territory needs constant monitoring and further studies on its ecological impacts. 


\section{Acknowledgements}

The authors are indebted to Dr. Alan J Paton, Head of Science Collections, Kew for confirming the identity of the species. The authors are also grateful to the Principal and Management, Nehru Arts and Science College, Kanhangad and 9 the Principal, Govt. College, Kasaragod for providing the necessary facilities.

\section{Authors contributions}

KSP collected the specimens and identified it based on the morphological characters. PB, KAT and EJJ helped in taking the photographs, arranging the colour plate and preparation of the manuscript. All authors read and approved the final manuscript.

\section{Compliance with ethical standards}

Conflict of interest: Authors do not have any conflict of interests to declare.

Ethical issues: None.

\section{References}

1. Paton AJ, Mwanyambo M, Govaerts RHA, Smitha K, Suddee S, Phillipson PB, Wilson TC, Forster PI, Culham A. Nomenclatural changes in Coleus and Plectranthus (Lamiaceae): a tale of more than two genera. PhytoKeys. 2019;129:1-158. https:// doi.org/10.3897/phytokeys.129.34988

2. Harley RM, Atkins S, Budantsev AL, Cantino PD, Conn BJ, Grayer $\mathrm{R}$ et al. editors. The Families and Genera of Vascular Plants 7. Springer, Berlin; 2004; p. 167-275. https://doi.org/10.1007/978-3642-18617-2_11

3. Lukhoba CW, Simmonds MSJ, Paton AJ. Plectranthus: A review of ethnobotanical uses. Journal of Ethnopharmacology. 2006;103 (1):1-24. https://doi.org/10.1016/j.jep.2005.09.011

4. Rice LJ, Brits GJ, Potgieter CJ, Van Staden J. Plectranthus: A plant for the future? South African Journal of Botany. 2011;77(4):94759. https://doi.org/10.1016/j.sajb.2011.07.001

5. Paton A, Mwanyambo M, Culham A. Phylogenetic study of Plectranthus, Coleus and allies (Lamiaceae): Taxonomy, distribution and medicinal use. Botanical Journal of the Lin-nean Society. 2018;188(4):355-76. https://doi.org/10.1093/botlinnean/boy064

6. Pollard BJ, Paton A. A new rheophytic species of Plectranthus L'Her. (Labiatae) from the Gulf of Guinea. Kew Bulletin. 2001;56 (4):975-82. https://doi.org/10.2307/4119309

7. Prendas SB, Alvarado RA, Vindas PS, Alvarez LP. First report of the weed Solenostemon monostachyus (P. Beauv.) Briq. (Fam. Lamiaceae) in agroecosystems in Costa Rica. Agronomia Mesoamericana. 2013;24(2):427-31. https://www.cabi.org/isc/ abstract/20143063881
8. Chung YS, Teo S, Chong KY, Kurukulasuriya BR, Tan HTW. Weed risk assessments of the exotic species of Plectranthus L'Her. (Lamiaceae) in Singapore. Nature in Singapore. 2015; 8:1-13. https://digitalgems.nus.edu.sg/shared/colls/blsea/files/ NatSin_n08_2015.pdf

9. Salleh N, Azeman S, Kiew R, Kamin I, Kong RCC. Plant checklist of the Bukit Nanas Forest Reserve, Kuala Lumpur, Malaysia. One Ecosystem. 2017; 2: e13708. https://www.cabi.org/isc/ abstract/20143063881

10. Irsyam ASD, Mountara A. Plectranthus monostachyus (P. Beauv.) B. J. Pollard (Lamiaceae) di Jawa. Floribunda. 2018;6(1):32-33. http://dx.doi.org/10.32556/floribunda.v6i1.2018.223

11. Smitha K. Taxonomic revision and molecular phylogeny of the genus Plectranthus (Lamiaceae). Botany, PhD [thesis]. Calicut: Calicut University; 2017.

12. Mathew J, Yohannan R, Conn BJ. Three new species of Plectranthus L'Hér. (Lamiaceae) from South Western Ghats, India. Telopea. 2017;20:179-91. https://openjournals.library.sydney.edu.au/ index.php/TEL/article/view/11470

13. Smitha K, Sunojkumar P. Plectranthus gamblei (Lamiaceae) sp. nov. from India and notes on the identity and lectotypification of P. bourneae. Nordic Journal of Botany. 2018; 36(8): e01639. https://doi.org/10.1111/njb.01639

14. Joseph T, Mathew J, George KV. Coleus anthonyi (Lamiaceae): a new species from South Western Ghats, India. Species. 2020;21 (68):337-42. https://www.researchgate.net/publication/346004441

15. Onu UO. Some pharmacological properties Solenostemon monostachyus. Journal of Herbs, Spices and Medicinal Plants. 1996;4 (2):3-7. https://doi.org/10.1300/J044v04n02_02

16. Jacques DY, Fidele K, Michel OA. Acute toxicity and antioxidant activity of hydroethanolic extract of Solenostemon monostachyus P. Beauv. leaves. Journal of Complementary and Integrative Medicine. 2010;7(1):45. https://doi.org/10.2202/1553-3840.1492

17. Okoko T, Ere D. Antioxidant activities of Solenostemon monostachyus leaf extract using in vitro methods. Scientific Research and Essays. 2012;7(6):621-26. https://academicjournals.org/ journal/SRE/article-full-text-pdf/93F818527970

18. Okokon J, Davis KA, Azare BA. Antipyretic and antimalarial activities of Solenostemon monostachyus. Pharmaceutical Biology. 2016;54(4):648-53. https://pubmed.ncbi.nlm.nih.gov/26474350/

19. Okokon JF, Davis K, Nwidu LL. Anti-inflammatory and antinociceptive activities of Solenostemon monostachyus aerial part extract in mice. Avicenna Journal of Phytomedicine. 2016;6 (3):284-94. https://pubmed.ncbi.nlm.nih.gov/27462551/ 